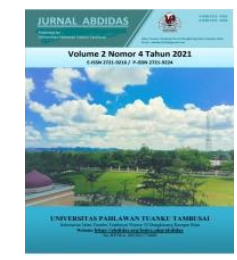

\title{
Perencanaan Program Berkelanjutan Usaha Mitra Els Cake Kota Painan, Kabupaten Pesisir Selatan
}

\author{
Putri Aulia Arza $^{1}$, Indah Permata Suryani ${ }^{2}$, Danny Hidayat $^{3}$, Yeni Sulastri ${ }^{4}$,Yen Elvince ${ }^{5}$ \\ Fakultas Kesehatan Masyarakat, Universitas Andalas, Indonesia ${ }^{1,3,4,5}$ \\ Fakultas Ekonomi, Universitas Andalas, Indonesia ${ }^{2}$ \\ E-mail : putriauliaarza@ph.unand.ac.id ${ }^{1}$ indahpermatasuryani@eb.unand.ac.id ${ }^{2}$ \\ dannyhidayat@eb.unand.ac.id ${ }^{3}$
}

\begin{abstract}
Abstrak
Permasalahan yang dihadapi "Els Cake" yaitu belum memiliki SIUP (Surat Izin Usaha Perusahaan) karena masih dikelola perorangan dan juga belum ada label halal. Dari aspek produksi yaitu karena belum adanya SIUP "Els Cake" mengalami kesulitan dalam mendapatkan modal usaha karena SIUP merupakan salah satu syarat untuk pinjaman modal usaha. Dari segi manajemen usaha, "Els Cake" belum memiliki struktur manajemen karena masih perorangan. Dari segi pemasaran masih bersifat tradisional, dan belum memanfaatkan pemasaran online untuk promosi dan penjualan. Walaupun ada akun Instagram belum optimal penggunaannya. Tujuan kegiatan ini yaitu untuk membantu mitra "Els Cake" untuk berkembang 3-5 tahun kedepan. Kegiatan direncanakan dilakukan dengan tatap muka ke lokasi dan dibarengi dengan pertemuan virtual secara daring karena masih dalam kondisi pandemik Covid 19. Tahap kegiatan pertama yaitu analisis kelemahan dan permasalahan usaha mitra, pertemuan tim dalam penyusunan rencana kegiatan akan dilakukan secara virtual menggunakan Zoom Meeting. Pembahasan rencana pengembangan dan penyepakatan pengembangan rencana kegiatan 3-5 tahun bersama mitra "Els Cake" direncanakan tatap muka dan pertemuan virtual dengan mendatangkan narasumber di bidang produksi, manajemen dan pemasaran. Hasil dan luaran yang diperoleh yaitu rencana program pengembangan mitra 3 tahun ke depan, rencana program pengembangan yang disepakati bersama mitra "Els cake" yaitu dari segi produksi, pemasaran dan manajemen usaha perlu untuk dibina dan didampingi. Luaran yaitu publikasi media massa dan video kegiatan terpublikasi di YouTube.
\end{abstract}

Kata kunci: pembinaan mitra, mitra tumbuh kembang, usaha makanan

\begin{abstract}
The problem faced by "Els Cake" is that it does not yet have a SIUP (Company Business License) because it is still managed individually and there is also no halal label. From the production aspect, namely because there is no SIUP, "Els Cake" has difficulty in obtaining business capital because SIUP is one of the requirements for business capital loans. From a business management perspective, "Els Cake" does not yet have a management structure because it is still an individual. Are traditional, and have not utilized online marketing for promotion and sales. Even though there is an Instagram account, its use is not optimal. The purpose of this activity is to help "Els Cake" partners to develop in the next 3-5 years. The activities are planned to be carried out face-to-face to the location and accompanied by online virtual meetings because it is still in a Covid-19 pandemic condition. The first activity stage is Analysis of partner business weaknesses and problems, Team meetings in the preparation of activity plans will be carried out virtually using a Zoom Meeting. Discussion on the development plan and agreement on the development of a 3-5 year activity plan with "Els Cake" partners are planned face-to-face and virtual meetings by inviting resource persons in the fields of production, management and marketing. The results and outputs obtained are the partner development program plan for the next 3 years, the development program plan agreed with the "Els cake" partner, namely in terms of production, marketing and business management needs to be fostered and assisted. The outputs are mass media publications and activity videos published on YouTube.
\end{abstract}

Keywords: partner development, development partners, food business

Copyright (c) 2021 Putri Aulia Arza, Indah Permata Suryani, Danny Hidayat, Yeni Sulastri' Yen Elvince $\triangle$ Corresponding author

Address : Kampus Universitas Andalas, Limau manis

Email : putriauliaarza@ph.unand.ac.id

DOI : https://doi.org/10.31004/abdidas.v2i4.407

ISSN 2721-9224 (Media Cetak)

ISSN 2721- 9216 (Media Online) 
1009 Perencanaan Program Berkelanjutan Usaha Mitra Els Cake Kota Painan, Kabupaten Pesisir Selatan - Putri Aulia Arza, Indah Permata Suryani, Danny Hidayat, Yeni Sulastri, Yen Elvince DOI: https://doi.org/10.31004/abdidas.v2i4.407

\section{PENDAHULUAN}

Usaha "Els Cake" yang dimiliki oleh Audina El'islami berdiri pada tahun 2018. Beliau mulai merintis usaha ini setelah selesai kuliah tata boga UNP. Adapun makanan-makanan yang dihasilkan yaitu aneka cake dan cookies, serta akhir-akhir ini sejak pandemik Covid-19, menjual makanan frozen food yaitu bakso dan risolle yang dibekukan. Aset yang dimiliki terdiri dari berbagai macam alat-alat memasak dan pembuat kue seperti oven, microwave, kulkas dan berbagai cetakan cake dan cookies. Ketua Mitra selama ini dibantu oleh 2 (dua) orang tim selama proses produksi sedangkan untuk manajemen keuangan dikelola sendiri oleh ketua mitra. Sistem penjualan masih bersifat tradisional harus datang ke rumah. Sementara adanya batasan keluar rumah menurunkan permintaan konsumen. Hal ini belum dapat diantisipasi karena usaha belum memiliki website atau aplikasi khusus untuk konsumen dapat memilih dan memesan produk secara daring, padahal kondisi pandemi dapat meningkatkan eksistensi bisnis online (Taufik \& Ayuningtyas, 2020).

Jenis makanan yang diproduksi pada umumnya adalah makanan basah yang mengakibatkan makanan tidak bisa disimpan lama sehingga beberapa makanan yang sudah terlanjur diproduksi sudah tidak layak konsumsi sehingga akhirnya dibuang yang mengakibatkan kerugian yang cukup besar. Berikutnya, produk mitra juga belum memiliki nilai tambah terhadap gizi yang cukup untuk mengambil selera pasar dalam penentuan jenis makanan yang memperkuat imun tubuh. Di samping itu, kurangnya diversifikasi produk misalnya produk berupa frozen food dan makanan kering yang dapat bertahan lebih lama (Arza \& Asmira, 2017). Dengan adanya diversifikasi produk, diharapkan terjadi peningkatan omset dari UKM seiring dengan peningkatan produksi produk (Khairani \& Pratiwi, 2018).

Omset dari usaha ini, bila di rata perbulannya sekitar 10 juta per bulan. Profil pelanggan yang dimiliki beragam mulai dari umum, pelajar, rumah tangga, hingga perkantoran. Sejak pandemi Covid-19 mulai terjadi dan diiringi dengan kebijakan Pembatasan Sosial Berskala Besar (PSBB) di Provinsi Sumatera Barat, khususnya Kota Painan, produktivitas dan pendapatan usaha ini turun sekitar kurang lebih 90\% dari pendapatan awal yang biasanya mencapai 10 juta perbulan, setelah pandemi paling banyak mendapatkan 2 juta. Bahkan pada bulan ini hanya sebanyak Rp. 500.000. Hal ini dikarenakan adanya penurunan daya beli masyarakat dan juga ketidaksiapan usaha ini di dalam diversifikasi produk, teknik pemasaran dan Teknologi Informasi dan Komunikasi (TIK) yang belum modern sehingga sulit menyesuaikan, sekaligus memperluas pangsa pasarnya di masa pandemi ini. Adapun tujuan dilakukan pengabdian ini yaitu untuk untuk membantu mitra "Els Cake" dalam membuat rencana program pengembangan untuk 3-5 tahun kedepan.

\section{METODE}

Kegiatan ini dilaksanakan selama 2 bulan yaitu dari bulan November sampai dengan Desember 2020. Lokasi kegiatan yaitu di Kota 
1010 Perencanaan Program Berkelanjutan Usaha Mitra Els Cake Kota Painan, Kabupaten Pesisir Selatan - Putri Aulia Arza, Indah Permata Suryani, Danny Hidayat, Yeni Sulastri, Yen Elvince DOI: https://doi.org/10.31004/abdidas.v2i4.407

Painan, Kabupaten Pesisir Selatan, Provinsi Sumatera Barat.

Pihak-pihak yang terlibat dalam kegiatan Pengembangan UKM Indonesia Bangkit. yaitu Mitra Els Cake, Dosen Bidang Gizi, Dosen Manajemen, Dosen Akuntansi, Narasumber terkait dan Lembaga penelitian dan pengabdian kepada masyarakat, Universitas Andalas.

Tabel 1 Tahapan Solusi Untuk Atasi Permasalahan Mitra

\begin{tabular}{|c|c|c|c|c|c|c|c|c|c|}
\hline \multirow{2}{*}{$\begin{array}{l}\mathbf{N} \\
\mathbf{0}\end{array}$} & \multirow{2}{*}{ Aktifitas } & \multicolumn{8}{|c|}{ Minggu } \\
\hline & & 1 & 2 & 3 & 4 & 5 & 6 & 7 & 8 \\
\hline 1. & $\begin{array}{l}\text { Analisis } \\
\text { kelemahan } \\
\text { dan } \\
\text { permasalahan } \\
\text { usaha mitra }\end{array}$ & $*$ & & & & & & & \\
\hline 2. & $\begin{array}{l}\text { Pertemuan } \\
\text { tim } \\
\text { penyusunan } \\
\text { rencana } \\
\text { kegiatan 3-5 } \\
\text { tahun }\end{array}$ & & $*$ & * & & & & & \\
\hline 3. & $\begin{array}{l}\text { Pertemuan I } \\
\text { pembahasan } \\
\text { rencana } \\
\text { pengembanga } \\
\text { n 3-5 tahun } \\
\text { dengan mitra }\end{array}$ & & & $*$ & $*$ & & & & \\
\hline 4. & $\begin{array}{l}\text { Pertemuan II } \\
\text { penyepakatan } \\
\text { pengembanga } \\
\text { n 3-5 tahun } \\
\text { dengan mitra }\end{array}$ & & & & & $*$ & * & & \\
\hline 5. & Seminar hasil & & & & & & & $*$ & \\
\hline 6. & $\begin{array}{l}\text { Laporan } \\
\text { akhir }\end{array}$ & & & & & & & & \\
\hline
\end{tabular}

Pertemuan dengan mitra akan dilakukan secara virtual menggunakan Zoom Meeting karena kondisi pandemi Covid-19 dan jika memungkinkan untuk pertemuan tahap 1 dengan mitra akan dilakukan secara tatap muka langsung ke lokasi mitra. Metode evaluasi dilakukan secara virtual menggunakan Zoom Meeting dan tatap muka dengan mitra dengan menerapkan protokol kesehatan karena kondisi pandemi Covid-19 mengacu kepada permasalahan yang dihadapi mitra. Pelaksanaan kegiatan dilakukan setiap solusi yang ditawarkan selesai dilakukan. Evaluasi akan dilakukan dengan pertemuan bersama tim dan mitra secara daring dengan menggunakan aplikasi Zoom Meeting.

\section{HASIL DAN PEMBAHASAN}

\section{Hasil Penyusunan Rencana Program}

Pengembangan yang Disepakati dengan Mitra

a. Pembinaan terhadap kelemahan dan permasalahan mitra;

b. Penguatan kinerja setiap manajemen sumberdaya manusia (SDM), tata kelola produksi dan pemasaran;

c. Pengembangan tata kelola produksi, manajemen SDM, dan pemasaran;

d. Peningkatan efisiensi tata kelola produksi, manajemen SDM, dan pemasaran serta kinerja;

e. Unggulan tata kelola produksi, manajemen SDM, dan pemasaran; 
1011 Perencanaan Program Berkelanjutan Usaha Mitra Els Cake Kota Painan, Kabupaten Pesisir Selatan - Putri Aulia Arza, Indah Permata Suryani, Danny Hidayat, Yeni Sulastri, Yen Elvince DOI: https://doi.org/10.31004/abdidas.v2i4.407

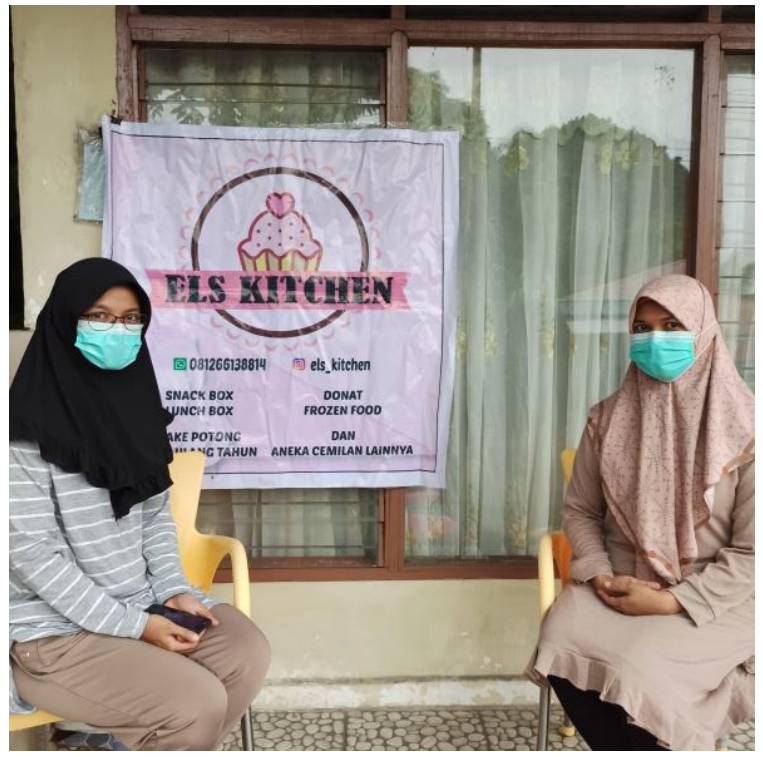

Gambar 1. Dokumentasi Wawancara untuk Merancang Program Berkelanjutan Membantu

Mitra Els Cake untuk Tumbuh Kembang

Berdasarkan hasil 4 (empat) kali pertemuan bersama mitra yang dilakukan secara tatap muka dan daring menggunakan aplikasi Zoom Meeting, dirumuskan akar masalah sebagai berikut :

Dari akar permasalahan yang muncul berdasarkan diagram fishbone tersebut, tahapan:

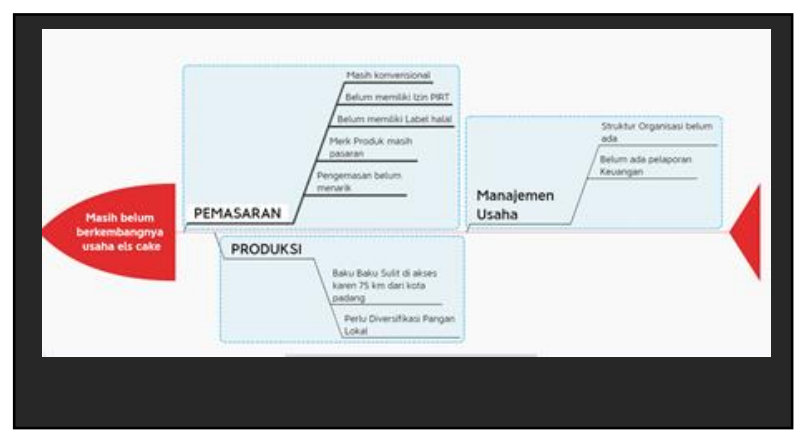

Gambar 2. Diagram Fishbone

Selanjutnya rencana program tahun 2021 yaitu menentukan solusi terbaik untuk pemecahan isu di atas yaitu dengan "Pembinaan terhadap kelemahan dan permasalahan mitra". Setelah didapatkannya akar masalah dan solusi untuk pemecahan masalah, tahap selanjutnya yaitu melakukan gap analysis untuk menemukan area yang dapat dioptimalkan dan membandingkan anatara kondisi saat ini dengan kondisi yang diharapkan. Adapun kondisi yang saat ini dan kondisi yang diharapkan dijelaskan pada Tabel 2.

Tabel 2. Kondisi Saat Ini dan Kondisi yang Diharapkan (Gap Analysis)

\begin{tabular}{|c|c|c|}
\hline $\begin{array}{l}\text { KONDISI } \\
\text { SAAT INI }\end{array}$ & GAP & $\begin{array}{c}\text { KONDISI } \\
\text { YANG } \\
\text { DIHARAPKAN }\end{array}$ \\
\hline PEMASARAN & & \\
\hline $\begin{array}{l}\text { Belum memiliki } \\
\text { PIRT, label halal } \\
\text { dan SIUP }\end{array}$ & \multirow{4}{*}{$\begin{array}{l}\text { Pembinaan } \\
\text { mitra dalam } \\
\text { pengurusan } \\
\text { SIUP, PIRT } \\
\text { dan label } \\
\text { halal }\end{array}$} & $\begin{array}{lr}\text { Adanya } & \text { SIUP, } \\
\text { izin PIRT dan } \\
\text { label halal }\end{array}$ \\
\hline $\begin{array}{l}\text { Merek produk } \\
\text { masih pasaran }\end{array}$ & & $\begin{array}{lr}\text { Perbaikan } & \text { merk } \\
\text { dagang yang } \\
\text { menarik dan } \\
\text { mudah diingat }\end{array}$ \\
\hline $\begin{array}{l}\text { Pengemasan } \\
\text { belum menarik }\end{array}$ & & \begin{tabular}{l}
\multicolumn{3}{l}{ Pengemasan } \\
sudah sesuai \\
dengan standar \\
syarat-syarat \\
pengemasan yang \\
baik
\end{tabular} \\
\hline $\begin{array}{l}\text { Teknik } \\
\text { pemasaran } \\
\text { masih } \\
\text { konvensional } \\
\end{array}$ & & Pemasaran online \\
\hline \multicolumn{3}{|l|}{ PRODUKSI } \\
\hline $\begin{array}{l}\text { Masih } \\
\text { tergantung pada } \\
\text { bahan baku } \\
\text { terutama tepung } \\
\text { terigu }\end{array}$ & $\begin{array}{l}\text { Pembinaan } \\
\text { Mitra }\end{array}$ & \begin{tabular}{l}
\multicolumn{2}{l}{ Diversifikasi } \\
pangan lokal \\
pengganti tepung \\
terigu
\end{tabular} \\
\hline \multicolumn{3}{|l|}{$\begin{array}{l}\text { MANAJEMEN } \\
\text { USAHA }\end{array}$} \\
\hline $\begin{array}{l}\text { Belum adanya } \\
\text { struktur } \\
\text { organisasi }\end{array}$ & $\begin{array}{l}\text { Pembinaan } \\
\text { Mitra }\end{array}$ & $\begin{array}{l}\text { Adanya struktur } \\
\text { organisasi mitra }\end{array}$ \\
\hline $\begin{array}{l}\text { Belum adanya } \\
\text { pelaporan } \\
\text { keuangan }\end{array}$ & & $\begin{array}{l}\text { Adanya pelaporan } \\
\text { Keuangan }\end{array}$ \\
\hline
\end{tabular}


1012 Perencanaan Program Berkelanjutan Usaha Mitra Els Cake Kota Painan, Kabupaten Pesisir Selatan - Putri Aulia Arza, Indah Permata Suryani, Danny Hidayat, Yeni Sulastri, Yen Elvince DOI: https://doi.org/10.31004/abdidas.v2i4.407

Tabel 3. Program Berkelanjutan Pengembangan Usaha Mitra Tahun 2021-2025

\begin{tabular}{|c|c|c|c|c|c|c|c|}
\hline \multirow{2}{*}{ NO } & \multirow{2}{*}{ PROGRAM } & \multicolumn{3}{|c|}{ PEMBINAAN } & \multicolumn{2}{|c|}{ PENDAMPINGAN } & \multirow{2}{*}{ OUTCOME } \\
\hline & & 2021 & 2022 & 2023 & 2024 & 2025 & \\
\hline 1. & $\begin{array}{lr}\text { Pembinaan } & \text { terhadap } \\
\text { kelemahan } & \text { dan } \\
\text { permasalahan mitra }\end{array}$ & $*$ & & & & & $\begin{array}{l}\text { Usaha } \\
\text { pelatihan } \\
\text { tentang } \\
\text { produksi, } \\
\text { teknik } \\
\text { pemasaran dan } \\
\text { manajemen } \\
\text { yang lengkap }\end{array}$ \\
\hline 2. & \begin{tabular}{lr} 
Penguatan & kinerja \\
setiap manajemen \\
Sumber \\
Manusia (SDMaya), \\
tata kelola produksi \\
\multicolumn{2}{c}{ dan pemasaran }
\end{tabular} & & * & & & & $\begin{array}{l}\text { Usaha kinerja } \\
\text { setiap } \\
\text { manajemen } \\
\text { Sumber Daya } \\
\text { Manusia } \\
\text { (SDM, tata } \\
\text { kelola produksi } \\
\text { dan pemasaran } \\
\text { yang kuat }\end{array}$ \\
\hline 3. & $\begin{array}{l}\text { Pengembangan tata } \\
\text { kelola produksi, } \\
\text { manajemen SDM, } \\
\text { dan pemasaran }\end{array}$ & & & * & & & $\begin{array}{l}\text { Usaha dengan } \\
\text { tata kelola } \\
\text { produksi, } \\
\text { manajemen } \\
\text { SDM, dan } \\
\text { pemasaran } \\
\text { yang } \\
\text { berkembang }\end{array}$ \\
\hline 4. & $\begin{array}{l}\text { Peningkatan efisiensi } \\
\text { tata kelola produksi, } \\
\text { manajemen SDM, } \\
\text { dan pemasaran serta } \\
\text { Kinerja }\end{array}$ & & & & * & & $\begin{array}{l}\text { Usaha dengan } \\
\text { tata kelola } \\
\text { produksi, } \\
\text { manajemen } \\
\text { SDM, dan } \\
\text { pemasaran } \\
\text { target kinerja } \\
\text { yang efisien }\end{array}$ \\
\hline 5. & $\begin{array}{l}\text { Unggulan tata kelola } \\
\text { produksi, manajemen } \\
\text { SDM, dan pemasaran }\end{array}$ & & & & & $*$ & $\begin{array}{l}\text { Usaha dengan } \\
\text { tata kelola } \\
\text { produksi, } \\
\text { manajemen } \\
\text { SDM, dan } \\
\text { pemasaran, } \\
\text { target kinerja } \\
\text { yang unggul }\end{array}$ \\
\hline
\end{tabular}

Hasil evaluasi kegiatan diperoleh Perencanaan Program Berkelanjutan Membantu Mitra Els Cake untuk Tumbuh Kembang dengan Usaha Makanan di Kota Painan, Kabupaten Pesisir Selatan dari segi produksi, makanan yang diproduksi yaitu aneka cake, cookies dan frozen food diproduksi sesuai permintaan saja, karena makanan ini bersifat mudah rusak. Label dan pengemasan juga masih hanya mencakup label merek dan No. HP penjual saja, belum memenuhi syarat label makanan menurut BPOM. Dari segi manajemen usaha, "Els Cake" belum memiliki 
1013 Perencanaan Program Berkelanjutan Usaha Mitra Els Cake Kota Painan, Kabupaten Pesisir Selatan - Putri Aulia Arza, Indah Permata Suryani, Danny Hidayat, Yeni Sulastri, Yen Elvince DOI: https://doi.org/10.31004/abdidas.v2i4.407

struktur manajemen karena masih perorangan dan dibantu oleh kerabat terdekat yang tidak di bidangnya jadi pembagian tupoksi masing-masing pekerja belum terorganisir dengan baik dan manajemen keuangan juga belum terlaksana dengan baik. Dari segi pemasaran masih bersifat tradisional, dan belum memanfaatkan pemasaran online untuk promosi dan penjualan. Walaupun ada akun Instragram belum optimal penggunaannya, ketercapaian tujuan kegiatan dampak dan manfaat setelah kegiatan dilakukan.

\section{SIMPULAN}

Adapun kesimpulan dari kegiatan pengabdian masyarakat Program Berkelanjutan Membantu Mitra Els Cake untuk Tumbuh Kembang dengan Usaha Makanan di Kota Painan, Kabupaten Pesisir Selatan ini yaitu akan dilakukan program pembinaan dalam bidang tata pamong, tata kelola, dan kinerja. Adapun 3 masalah utama yang sudah disepakati bersama mitra yang akan dilakukan pembinaan dan pendampingan 3 tahun ke depan yaitu dari segi produksi, pemasaran dan manajemen usaha.

\section{UCAPAN TERIMA KASIH}

Terima kasih diaturkan kepada Universitas Andalas yang telah mendanai kegiatan ini melalui Hibah BOPTN LPPM UNAND Tahun 2020, sehingga dapat terlaksananya kegiatan ini dengan mitra ELS CAKE, Kabupaten Pesisir Selatan. Terima kasih kami ucapkan juga kepada mitra yang telah bekerjasama sehingga tercapainya tujuan yang diharapkan.

\section{DAFTAR PUSTAKA}

Arza, P. A., \& Asmira, S. (2017). PENGARUH PENAMBAHAN LABU KUNING (Cucurbita moschata) dan Ikan Gabus (Ophiocephalus striatus) TERHADAP MUTU ORAGNOLEPTIK, KADAR PROTEIN DAN VITAMIN A BISKUIT. Nutri-Sains: Jurnal Gizi, Pangan Dan Aplikasinya, 1(1), 58-66.

Khairani, S., \& Pratiwi, R. (2018). Peningkatan Omset Penjualan Melalui Diversifikasi Produk dan Strategi Promosi Pada UMKM Kerajinan Souvenir Khas Palembang. CARADDE: Jurnal Pengabdian Kepada Masyarakat, 1(1), 36-43.

Taufik, T., \& Ayuningtyas, E. A. (2020). DAMPAK PANDEMI COVID 19 TERHADAP BISNIS DAN EKSISTENSI PLATFORM ONLINE. Jurnal Pengembangan Wiraswasta, 22(01), 21-32. 